\title{
BENTUK KEGIATAN PEMBELAJARAN SENI RUPA DI TAMAN KANAK-KANAK MUTIARA ANANDA PADANG
}

\author{
Pitria Gusliati ${ }^{1}$, Farida Mayar ${ }^{2}$ \\ Fakultas Ilmu Pendidikan, Universitas Negeri Padang ${ }^{1}$ \\ Fakultas Ilmu Pendidikan, Universitas Negeri Padang ${ }^{2}$ \\ Email: pitria_gusliati@yahoo.com ${ }^{1}$,Email: mayarfarida@gmail.com²
}

\begin{abstract}
Abstrak
Seni rupa merupakan pembuatan berbagai macam hasil karya yang dapat dilihat, diraba, dan dirasakan dengan memanfaatkan berbagai media. Seni rupa terdiri atas dua macam, yaitu seni rupa murni dan seni rupa terapan. Pada dasarnya semua bentuk seni rupa berkaitan dengan keindahan. Adapun tujuan penulisan artikel ini adalah untuk mengetahui bentuk kegiatan pembelajaran seni rupa di Taman Kanak-kanak Mutiara Ananda Padang. Adapun metode yang digunakan yaitu deskriptif kualitatif dengan pendekatan survey. Alat pengumpulan data yang digunakan adalah wawancara dan observasi. Hasil penelitian menunjukkan bahwa bentuk-bentuk pembelajaran seni rupa yang dilaksanakan di Taman Kanak-kanak Mutiara Ananda Padang berupa kegiatan menjiplak, menggambar, membentuk, finger painting, mencetak, dan kolase. Pembelajaran seni rupa dilaksanakan seusuai tema pembelajaran dan berbagai macam media pembelajaran.
\end{abstract}

Kata kunci: pelaksanaan, pembelajaran, seni rupa

\begin{abstract}
Fine art is the making of various kinds of works that can be seen, touched, and felt by utilizing various media. There are two kinds of art, namely pure art and applied art. Basically, all forms of art are related to beauty. The purpose of writing this article is to find out the form of art learning activities in Kindergarten of Mutiara Ananda Padang. The method used is descriptive qualitative survey approach. Data collection tools used were interviews, observation, and documentation. The results showed that the forms of art learning conducted in the kindergarten of Mutiara Ananda Padang in the form of plagiarism, drawing, shaping, finger painting, printing, and collage activities. Fine art learning is carried out after the learning theme and various kinds of learning media.
\end{abstract}

Keywords: implementation, learning, fine arts. 


\section{PENDAHULUAN}

Pendidikan merupakan proses sosialisasi menuju kedewasaan seluruh aspek perkembangan sesuai dengan kemampuan yang dimiliki individu. Melalui pendidikan semua potensi yang dimiliki anak dapat dikembangkan dengan sebaik-baiknya, maka dari itu pendidikan sangat penting diberikan sejak dini. Karena pada usia dini adalah masa yang paling baik untuk mengembangkan potensi anak.

Lembaga pendidikan anak usia dini dapat mengembangkan potensi yang ada pada diri anak secara optimal. Perkembangan tersebut dapat dilakukan melalui media-media pembelajaran yang berbentuk alat permainan, karena permainan merupakan salah satu sarana untuk mengembangakan potensi-potensi yang ada pada anak usia dini adalah bermain sambil belajar, belajar seraya bermain.

Masa anak-anak disebut juga dengan masa emas (golden age). Untuk itu pendidikan anak usia dini harus di desain sesuai dengan kodrat anak-anak dan perlahan membimbing anak, agar bisa mengembangkan segala aspek perkembangan baik kognitif, fisik motorik, bahasa, maupun seni. Salah satu kemampuan yang harus dikembangkan pada anak usia dini adalah kemampuan seni. Kemampuan seni dapat distimulasi melalui berbagai macam kegiatan pembelajaran, salah satunya melalui pembelajaran seni rupa. Berbagai macam hasil karya seni rupa anak dapat dilihat dari bentuk pembelajaran seni rupa yang dilakukan, penggunaan warna, dan teknik pembuatan karya seni rupa. Kegiatan seni rupa memberikan kebebasan pada anak dalam mengeksplorasi media yang dipakai. Kebebasan dalam memilih media akan menghasilkan karya yang beragam, pengunaan teknik dalam berbagai media, sifat khas media serta melihat orang lain menggunakannya.

Keberhasilan pendidikan seni rupa kembali pada kemampuan guru memahami karakteristik seni anak untuk diterapkan sesuai dengan tahap perkembangannya. Banyak hal yang dapat dikembangkan dalam kegiatan seni rupa, diantaranya yaitu mengembangkan kreativitas anak karena seni rupa membuat anak usia dini berekspresi dalam menghasilkan suatu karya yang memiliki susunan artistic seperti warna, tekstur, volume, dan ruang. Pembelajaran seni rupa juga mampu mengembangkan imajinasi anak yang nantinya dapa menstimulasi ide-ide baru yang kreatif. 
Berdasarkan hal tersebut penulis merasa tertarik untuk melakukan penelitian tentang pelaksanaan pembelajaran seni rupa di Taman Kanakkanak Mutiara Ananda Padang. Tujuan penelitian ini adalah untuk melihat gambaran bentuk kegiatan pembelajaran seni rupa di lembaga tersebut.

Pendidikan seni sangat berkontribusi dalam membantu perkembangan anak usia dini, diantaranya yaitu perkembangan mental, kreativitas, keindahan, emosional, fisik, dan sosial anak usia dini. Menurut (Dwi, Erlia Pratiwi Bahri dan Sattar, 2017) seni rupa merupakan media untuk mengungkapkan gagasan dan ide-ide serta pengalaman dalam merespon segala fenomena kehidupan yang dialami. Pembelajaran seni rupa adalah suatu proses belajar yang lebih menekankan pada penggunaan unsurunsur rupa garis, warna, tekstur, bidang, bentuk, dan ruang yang dapat dinikmati secara visual (Purnamasari, 2009).

Tujuan utama dari pembelajaran seni rupa menurut (O. dan I. Garha, 1978) adalah mengembangkan daya cipta anak melalui ide-ide, imajinasi, serta fantasi anak dalam menyalurkan perasaannya dalam bentuk yang kreatif. (Salam, 2001) menjelaskan bahwa pembelajaran seni rupa pada anak dapat dilakukan

melalui

kegiatan

menggunting, mencetak, menggambar, melipat, menempel, membutsir, memahat, merangkai, membatik, dan menganyam. Seluruh kegiatan tersebut dapat terlaksana jika guru memfasilitasi dengan media yang sesuai.

(Sobandi, 2008) menjelaskan bahwa pendidikan seni rupa sebagai sarana pendidikan formal dan nonformal yang berfungsi mengembangkan gagasan, nilai, fikiran tentang keindahan. (Wahyuni, 2011) menyebutkan bahwa ada 2 aspek dari tujuan pembelajaran seni rupa, yaitu kemampuan apresiasi terhadap hasil karya dan kemampuan untuk berkreasi yang pada akhirnya anak berperan serta dalam seni budaya di tingkat lokal, regional, maupun global.

Dapat disimpulkan bahwa seni rupa adalah suatu keterampilan yang diperoleh melalui proses belajar dalam mengungkapkan segala ide, gagasan, maupun pengalaman yang dapat dinikmati secara visual. Karya seni rupa menurut (O. dan B. Garha, 1975) terdiri atas dua jeni, yaitu:

Karya seni rupa dua dimensiMerupakan karya seni rupa yang diwujudkan dalam bidang datar yang memiliki ukuran panjang dan lebar. Seperti: lukisan, gambar, sketsa, dll. Karya seni rupa tiga dimensi Merupakan karya seni rupa yang 
memiliki volume berupa panjang, lebar, dan tinggi. Contohnya: patung.

Seni rupa akan terwujud jika guru memfasilitasi anak dengan berbagai macam media pembelajaran. Karena media pembelajaran sangat mempengaruhi minat anak dalam berkarya. Sehingga anak lebih leluasa menuangkan imajinasi dan gagasannya baik berupa goresan, maupun hasil olahan jari jemari anak usia dini.

\section{METODE PENELITIAN}

Penelitian ini menggunakan metode deskriptif kualitatif dengan pendekatan survey. Menurut (Abdurrahman, 2006) penelitian deskriptif yaitu sesuatu penelitian yang bermaksud mengadakan pemeriksaan dan pengukuran-pengukuran tertentu terhadap gejala tertentu. Selanjutnya (Sugiyono, 2010) menyebutkan bahwa kualitatif adalah sebuah pendekatan penelitian naturalistik, karena penelitian yang dilakukan pada kondisi yang alamiah. Penelitian ini dilaksanakan di Taman Kanak-kanak Mutiara Ananda Padang pada bulan September s.d November 2019. Adapun subjek penelitian ini adalah anak usia 4-6 tahun yang berjumlah 45 orang. Pengumpulan data menggunakan teknik wawancara dan observasi.

\section{HASIL PENELITIAN DAN PEMBAHASAN}

Berdasarkan wawancara dan observasi yang dilakukan di Taman Kanak-kanak Mutiara Ananda Padang diperoleh informasi bahwa bentuk pelaksanaan pembelajaran seni rupa sebagai berikut:

1. Menggambar

TK Mutiara Ananda Padang memberikan kesempatan pada anak usia dini dalam menuangkan imajinasinya melalui kegiatan menggambar. Berdasarkan hasil observasi yang dilakukan, guru memfasilitasi anak dengan buku gambar, pensil, crayon, dan spidol warna dalam kegiatan menggambar. Anak melakukan kegiatan menggambar sesuai tema yang dipelajari. Anak diberi kebebasan dalam membuat gambar sesuai keinginan mereka. Pengertian menggambar menurut (Tresaningsih, 2015) adalah proses pengungkapan imajinasi, perasaan, dan ekspresi anak melalui kegiatan yang membutuhkan alat gambar tanpa adanya unsure paksaan. Menggambar ialah kegiatan menggores permukaan menggunakan alat gambar dalam menuangkan imajinasi anak usia dini 
(Purwitaningtyas,

2014).

Menggambar merupakan suatu ungkapan perasaan anak usia dini baik mental maupun visual dalam bentuk coretan-coretan dan warna dalam menuangkan ide dan perasaan melalui pemerolehan dari penglihatan menggunakan alat gambar tertentu.

\section{Mencetak}

Kegiatan seni rupa yang dilakukan di TK Mutiara Ananda salah satunya yaitu melalui kegiatan mencetak. Wawancara dengan Ibu Delvi Ratnawita menyebutkan bahwa anak melakukan kegiatan mencetak menggunakan penampang berbagai buah-buahan dan batang tumbuhtumbuhan ataupun benda lainnya. Biasanya anak mencetak menggunakan buah belimbing, pelepah pisang, pelepah keladi, bentuk daun-daunan, dan lainnya. Selain itu, guru juga menyediakan stempel yang diberi tinta dengan berbagai macam warna. Mencetak menurut (Supriyenti, 2013) adalah suatu cara untuk memperbanyak gambar dengan alat cetak yang telah disediakan. Mencetak merupakan proses mencapkan alat yang telah diberi tinta pada kertas gambar dalam kegiatan seni rupa (Sumanto,
2005). Pengertian mencetak pada pembelajaran seni rupa anak usia dini adalah kegiatan mencap menggunakan ruas penampang seperti penampang dari buah belimbing, batang keladi, dan sebagainya dengan menempelkan ruas penampang pada tinta yang telah disediakan dan mengaplikasikannya di kertas.

3. Membentuk

Hasil observasi yang dilakukan menunjukkan bahwa anak melakukan kegiatan membentuk menggunakan playdough. Guru menyediakan berbagai macam warna playdough. Anak melakukan kegiatan membentuk menggunakan playdough sesuai tema pembelajaran. Playdough menurut (Mayesky, 2005) ialah suatu bahan yang sangat lembut dan fleksibel yang dapat membuat anak mengekspresikan kreativitasnya. Saat kegiatan membentuk anak bebas berkreasi sesuai keinginan. (Pamadhi, Hajar \& Sukardi, 2008) menjelaskan bahwa tujuan kegiatan membentuk adalah melatih pengamatan, melatih ketelitian, melatih kecermatan, melatih kemampuan motorik halus, melatih kreativitas, melatih kepekaan 
akan keindahan, dan melatih ketepatan.

Jadi, kegiatan membentuk merupakan kegiatan yang mampu merangsang kemampuan seni anak usia dini dalam membuat berbagai bentuk menggunakan bahan yang lembut dan lentur.

\section{Finger painting}

TK Mutiara Ananda Padang melakukan kegiatan seni rupa salah satunya berupa finger painting. Alat dan bahan yang digunakan berdasarkan hasil observasi adalah cat air, kertas ukuran A4, dan lem kayu. (Sumanto, 2005) mendefinisikan finger painting sebagai suatu kegiatan yang dilakukan oleh anak dalam menggambar dengan cara menggunakan warna dengan jari tangan secara langsung diatas bidang gambar. Finger painting yaitu suatu pembelajaran berupa kegiatan melukis menggunakan seluruh jari tangan sebagai alatnya secara langsung dengan media pewarna cair (Sudarmawan, 2010). Dapat disimpulkan bahwa pembelajaran finger painting adalah suatu kegiatan pembelajaran yang melibatkan jari jemari anak usia dini yang langsung dicelupkan kedalam pewarna menggunakan lem yang memungkinkan anak berkreasi sesuai imajinasinya.

\section{Kolase}

Hasil observasi menunjukkan bahwa kegiatan kolase yang dilakukan anak usia dini di TK Mutiara Ananda Padang menggunakan biji-bijian, ampas kelapa, dan potongan kertas warna. menurut ibu Adek selaku guru kelas B2 menjelaskan bahwa anak melakukan kolase sesuai tema pembelajaran. Guru menyediakan pola pada kertas, selanjutnya anak diminta untuk mengisi pola menggunakan bahan yang telah disediakan. (Sumanto, 2005) menjelaskan bahwa kolase ialah suatu kreasi seni yang dibuat dengan menggabungkan antara lukisan tangan dengan menempelkan bahanbahan tertentu. (Purbowati \& Reza, n.d.) menyebutkan bahwa bahan yang digunakan dalam teknik kolase adalah berupa bahan alam (kulit batang pisang kering, batu-batuan), bahan olahan (kapas, benang, kain perca, kertas berwarna), dan bahan 
bekas (kertas Koran, kalender bekas, majalah bekas, tutup botol).

6. Menjiplak

Wawancara dengan Ibu Wira Wahyuni menyatakan bahwa anak usia dini diminta melakukan kegiatan menjiplak menggunakan uang koin. Alat dan bahan yang digunakan adalah uang koin, pensil, dan kertas ukuran A4. Cara kerjanya adalah anak melatakkan uang koin dibawah kertas A4. Selanjutnya permukaan uang koin yang ada dikertas di arsir menggunakan pensil. Hasilnya tekstur dan tulisan yang tertera pada uang koin akan muncul pada kertas yang telah di arsir. Menjiplak adalah suatu kegiatan meniru suatu bentuk dari jiplakan yang sudah ada (Wahyuni, 2011). Menjiplak dapat menghadirkan rasa senang kepada anak usia dini karena anak merasa mampu membuat hasil karya persis seperti aslinya.

\section{SIMPULAN}

Seni rupa merupakan suatu keterampilan yang diperoleh melalui proses belajar dalam mengungkapkan segala ide, gagasan, maupun pengalaman yang dapat dinikmati secara visual. Ada berbagai bentuk kegiatan seni rupa yang dilakukan di TK Mutiara Ananda
Padang, diantaranya yaitu menjiplak, menggambar, membentuk, finger painting, mencetak, dan kolase. Kegiatan ini dilaksanakan pada setiap tema pembelajaran, tentunya dengan alat dan bahan yang berbeda. Kegiatan seni rupa dapat menstimulasi perkembangan anak usia dini, khususnya perkembangan seni. Untuk itu, hasil penelitian ini hendkanya dpaat menjadi acuan bagi guru anak usia dini dalam memvariasikan kegiatan seni rupa di lembaga PAUD.

\section{DAFTAR PUSTAKA}

Abdurrahman, F. (2006). Metodologi Penelitian dan Teknik Penyusunan Skripsi. Jakarta: Rineka Cipta.

Dwi, Erlia Pratiwi Bahri dan Sattar, M. (2017). Karakter Bubbledolls Sebagai Penciptaan Seni Lukis Erlia Dwi Pratiwi Bahri Abstrak. 05, 119-127.

Garha, O. dan B. (1975). Penuntun Pendidikan Seni Rupa untuk SD. Bandung: Pelita masa.

Garha, O. dan I. (1978). Pendidikan Kesenian Seni Rupa. Jakarta: Rosa Karya Offset.

Mayesky, M. (2005). Creative Art \& Activities Fun With Art! United States: Thomson Delmar Learning.

Pamadhi, Hajar \& Sukardi, E. S. (2008). Seni Keterampilan Anak. Jakarta: Universitas Terbuka.

Purbowati, E., \& Reza, M. (n.d.). Meningkatkan Kemampuan Motorik Halus Melalui Kegiatan Kolase Pada Anak Usia 3 - 4 Tahun Di Ppt Siaga SurabayA. 1-8.

Purnamasari, M. D. (2009). Kompetensi Kreatif Siswa Sma Muhammadiyah Purwodadi 
Dalam Pembelajaran Seni Rupa.

Purwitaningtyas, R. (2014). Meningkatkan Kecerdasan Visual Spasial Anak Melalui Kegiatan Menggambar Dengan Menggunakan Pendekatan Pembelajaran Kontekstual pada Kelompok Usia 3-4 Tahun di PPT Harapan bangsa Surabaya.

Salam, S. (2001). Pendidikan Seni Rupa di Sekolah Dasar. Buku Ajar. Makassar: Universitas Negeri Makassar.

Sobandi, B. (2008). Model Pembelajaran Kritik dan Apresiasi Seni Rupa. Solo: Maulana Offset.

Sudarmawan, A. (2010). Pelaksanaan Pembelajaran Finger Painting Kelompok B di TK Negeri Pembina Singaraja. (1), $1-11$.

Sugiyono. (2010). Metode Penelitian Pendidikan. Bandung: Alfabeta.

Sumanto. (2005). Pengembangan Kreativitas Seni Rupa Anak TK. Jakarta: Departemen Pendidikan Nasional. Direktorat Jenderal Manajemen Pendidikan Dasar dan Menengah, Direktorat Pembinaan Taman Kanakkanak dan Sekolah Dasar.

Supriyenti, A. (2013). Meningkatkan Kreativitas Seni Rupa Anak Melalui Kegiatan Mencetak dengan Bahan Alam di PAUD Aisyiyah Lansano Pesisir Selatan. Spektrum PLS UNP, I No 2(20).

Tresaningsih, W. (2015). Kemampuan Menggambar Bebas Sebelum Pembelajaran Anak TK Kelompok A Dan B TK Al 'Idad An-Nur.

Wahyuni, D. K. (2011). Studi Eksploratif Pemanfaatan Grajen Warna Sebagai Media Pengembangan Kreativitas Dalam Berkarya Seni Membentuk. 
Bentuk Kegiatan Pembelajaran

Pitria Gusliati 1

Farida Mayar ${ }^{2}$ 